\title{
The Trace Element Characteristics of Shales from Upper Ordovician-Lower Silurian in Wuling Depression: Implication for Block Amalgamation Time and Tectonic Setting
}

\author{
Yuan-yuan PENG \\ School of Energy Resources, CUGB \\ Beijing 100083, China \\ E-mail: 854946290@qq.com \\ Hui-yu HAN \\ School of Energy Resources, CUGB \\ Beijing 100083, China \\ E-mail: 2425065222@qq.com
}

\author{
Zhi-hong KANG* \\ School of Energy Resources, CUGB \\ Beijing 100083, China \\ E-mail:250586274@qq.com
}

Lei ZHOU

School of Energy Resources, CUGB

Beijing 100083, China

E-mail: 755302856@qq.com

\begin{abstract}
The collision time of the Yangtze Block and the Cathaysia Block has been controversial for decades. This paper discusses the sedimentary provenance and tectonic setting through the analysis of the trace element characteristics. The study results suggests that the Yangtze Block and Cathaysia Block were still in collision between the Ordovician and Silurian.
\end{abstract} shale

Keywords-Wuling depression; block; tectonic; trace element;

\section{INTRODUCTION}

The South China Block is composed of the Yangtze Block in the northwest and the Cathaysia Block in the southeast. However, the collision time of the Yangtze Block and the Cathaysia Block has been controversial for decades. A main view suggested that there was an ocean existed between the Yangtze Block and the Cathaysia Block for at least the latest Neoproterozoic to Cambrian period or even until the Jurassic before the two blocks get impacted. Another alternative view suggested that the amalgamation of the two blocks had been completed by the Neoproterozoic period [7].

Previous studies showed that the geochemical characteristics of shale could indicate of sedimentary provenance and tectonic setting [1-6,8]. In this paper, block amalgamation time and tectonic setting has been investigated through trace element and rare earth element of shale samples from Upper Ordovician Wufeng Formation and Lower Silurian Longmaxi Formation in Wuling depression.

\section{DISCUSSION}

\section{A. Sedimentary Provenance}

The Rare earth element (REE) distribution patterns of shale is commonly an indicator of provenance. The distribution pattern of REE in the Upper Crust was rich in
Light rare earth element (LREE), diluted in Heavy rare earth element (HREE) and negative anomaly Eu [5-6].

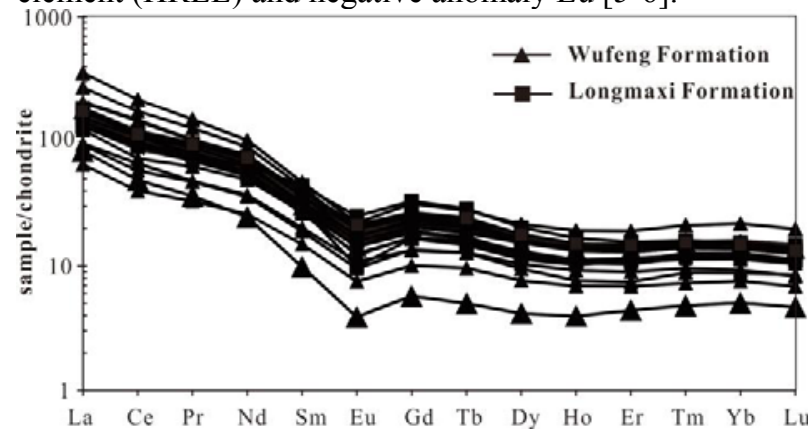

Figure 1. The REE distribution patterns of shale in study area (The chondrite-normalized data from Taylor and McLennan ${ }^{[6]}$ )

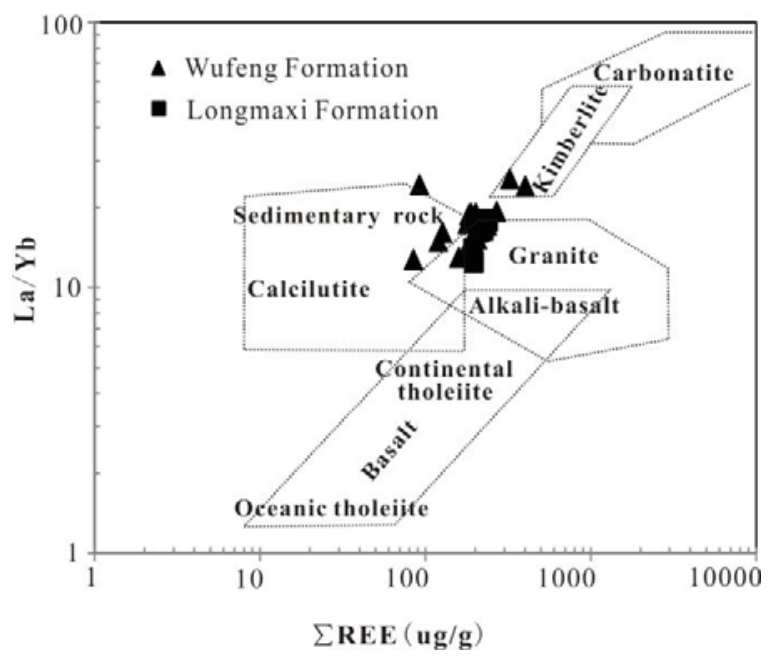

Figure 2. Discrimination diagram of $\sum \mathrm{REE}-\mathrm{La} / \mathrm{Yb}$ for provenance attribute of shale in study area (Modified according to Allegre ${ }^{[1]}$ ) 
As shown in Fig.1, the distribution pattern of the REE normalized to chondrite in Shale samples was akin to the Upper Crust, suggesting that the provenance was stable during the sedimentary process and the provenance was from the Upper Crust.

As shown in the Fig.2, the plots of rare earth elements ( $\Sigma \mathrm{REE})$ and $\mathrm{La} / \mathrm{Yb}$ indicated the source rock was felsic provenance, mixed with more granite and a small amount of kimberlite. The discrimination diagram of Hf-La/Th and $\mathrm{La} / \mathrm{Sc}-\mathrm{Co} / \mathrm{Th}$ could also analyze the provenance property. The diagram of Hf-La/Th also indicated of the felsic provenance (Fig.3a), as well as the Upper Crust. In addition, we could know that the felsic provenance might be accompanied with the intrusion of andesite and granite using the diagram of $\mathrm{La} / \mathrm{Sc}-\mathrm{Co} / \mathrm{Th}$ (Fig.3b).

\section{B. Tectonic Setting}

The trace elements (such as $\mathrm{Th}, \mathrm{Sc}, \mathrm{Zr}$ etc.) could be frequently used to discriminate the tectonic setting of the sedimentary basin [2-3]. The plots of La-Th-Sc, Th-Sc$\mathrm{Zr} / 10$, Th-Co- $\mathrm{Zr} / 10$ substantiated that the tectonic setting was the active continental margin area (Fig.4). The provenance is different from previous studies, besides, tectonic setting revealed that the Yangtze Block and the Cathaysia Block could still be in the colliding status during the Ordovician-Silurian period.

\section{CONCLUSIONS}

1. The source rock of Ordovician-Silurian shale was from the upper earth crust and mixed with more granite and few andesite, kimberlite, suggested shales were not derived from the clastic sediment from Ordovician Wufeng formation to Silurian Longmaxi formation.
2. The La-Th-Sc, Th-Sc-Zr and Th-Co-Zr discrimination diagram of shale indicated that the tectonic setting was mainly the active continental margin.

3. Through the analysis of the sedimentary provenance and tectonic setting, the Yangtze Block and Cathaysia Block were still in collision between the Ordovician and Silurian.

\section{REFERENCES}

[1] Allegre C T, Quantitative models of trace element behavior in magmatic process[J]. Earth Planet Science Letter, 1978,38(1):1-25.

[2] Bhatia M R. 1985. Rare earth element geochemistry of Australian Paleozoic graywackes and mudstone:Provenance and tectonic control[J]. Sedimentary Geology, 91:97-133.

[3] Bhatia M R and Crook K W. 1986. Trace element characteristics of gray wackes and tectonic setting discrimination of sedimentary basin[J]. Contributions to Mineralogy and Petrology, 92:181-193.

[4] Floyd P A, Leveridge B E. 1987. Tectonic Environment of Devonia Gramscatho basin,South Cornwall: Framwork mode and geochemical evidence from turbiditic sandstones[J]. Geological Society of London Journal, 144:531-542.

[5] McLennan S M. 1989. Rare earth element in sedimentary rock:Influence of provenance and sedimentary processes(In:Lipin B R,Mckay G A eds.Geochemistry and Mineralogy of Rare Earth Element)[J]. Review Mineralogy, 21:169-200.

[6] McLennan S M and Taylor S R. 1991. Sedimentary rocks and crustal evolution:Tectonic setting and secular trends. The Journal of Geology, 99(1):1-21.

[7] Wei-Hua Yao,Zheng-Xiang Li and Wu-Xian Li.2015.Was there a Cambrian ocean in South China? Insight from detrital provenance analyses[J].Cambridge University Press,152(1):184-191.

[8] Wronliewicz D J,Condie K C. 1987. Geochemistry of Archean shales from the Witwatersr and Supergroup,South Africa:Source-area weathering and provenance $[\mathrm{J}]$. Geochemica et Cosmochimica Acta, 51:2401-2416.
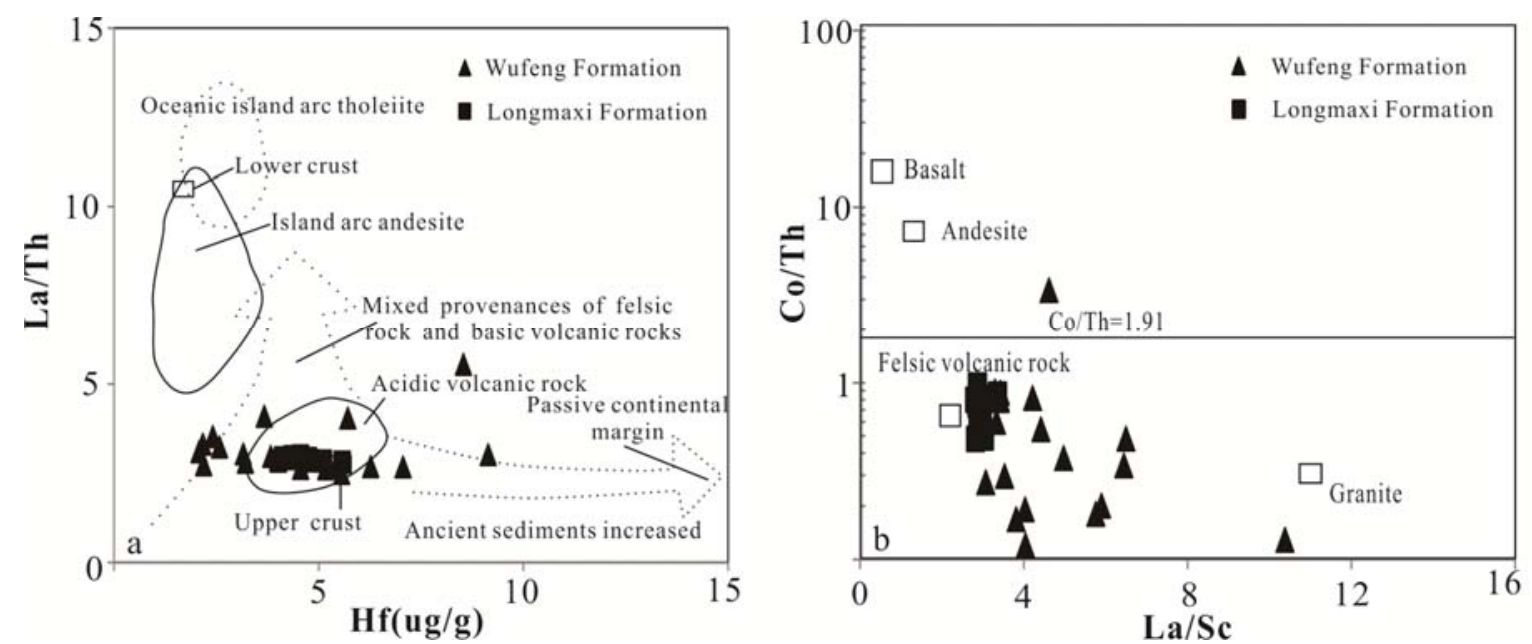

Figure 3. Discrimination diagram of $\mathrm{Hf}-\mathrm{La} / \mathrm{Th}$ and $\mathrm{La} / \mathrm{Sc}-\mathrm{Co} / \mathrm{Th}$ for provenance attribute of shale in study area(a-Modified according to Floyd and Leveridge $^{[4]}$, b-Modified according to Wronliewicz and Condie ${ }^{[8]}$ ) 


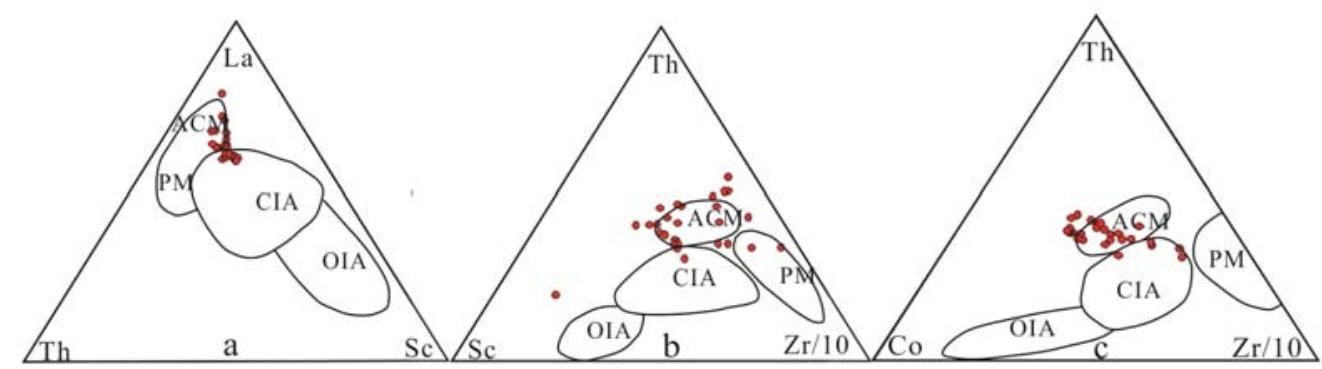

Figure 4. Discrimination diagram for tectonic setting of shale in study area(Modified according to Bhatia and Crook ${ }^{[2-3]}$ ).Tectonic setting: CIA continental island arc: OIA oceanic island arc: ACM active continental margin; PM passive continental margin 